\title{
An analysis of sales of coal products with reference to environmental regulations of the European Union
}

\author{
Anna Manowska ${ }^{1, *}$, Aurelia Rybak $^{1}$ \\ ${ }^{1}$ Department of Electrical Engineering and Automation in Industry, Faculty of Mining, Safety \\ Engineering and Industrial Automation, Silesian University of Technology, 2A Akademicka St., 44- \\ 100 Gliwice, Poland,
}

\begin{abstract}
Hard-coal mines deliver coal with crucially diversified quality parameters to the energy market, thus demonstrating the considerable production capacity of the coal industry, which endeavours to adapt to the high quality demands of the market. An essential element influencing the situation of the Polish coal sector is its regulatory environment. European directives transposed to the domestic legislative system are mainly aimed at decarbonisation, which will result in a significant reduction of the economic role of the qualitatively worst coals. The impact of these regulations on the functioning energy and fuel sectors poses a challenge for both the mining industry and energy companies. Once Poland joined the European Union, the issue of mechanical processing, which influences the quality of market coal, became a major issue due to effective European coal quality requirements. The present article presents an analysis of the potential for selling hard coal in reference to environmental regulations of the European Union. This analysis enabled the development of a theoretical model for forecasting demand on the domestic market. A proper forecast of demand enables flexible and dynamic adjustment of levels of production or inventory to changes taking place in the market.
\end{abstract}

\section{Introduction}

The European Union member states, having established a common energy policy, are endeavouring to adjust its major goals to specific conditions in particular countries. These adjustments refer mainly to the protection of consumers' interests, individual energy resources, and technological conditions of energy production and transfer. The basic trends in European energy policy are as follows:

- improvement of energy efficiency;

- increased safety of fuel and energy deliveries;

- diversification of the structure of electrical energy production through the introduction of nuclear energy;

- development of renewable energy sources, including biofuels.

\footnotetext{
* Corresponding author: anna.manowska@polsl.pl
} 
To a large extent the adopted goals of the energy policy are being achieved. European Union members place great emphasis on improving energy efficiency, which reduces demand for fuel and energy and contributes to increasing energy security as a result of decreased dependence on imports, while limiting the impact of energy consumption on the environment through the reduction of emissions. Following these trends, the energy policy strives to raise the energy security of countries while maintaining the principles of sustainable development.

Poland's energy policy until 2040 is a new strategy currently being prepared by the Ministry of Energy, which is to be the answer to the most important challenges facing the Polish energy sector and will set the directions for the development of the energy sector [1]. The essential element of this strategy are prognostic analyzes in the scope of covering the demand for electricity. Poland has rich resources of hard and brown coal and the energy mix is mainly based on coal. The stringent environmental requirements currently in force in EU countries are associated with the mandatory costs of climate and environmental policy, which has an impact on the competitiveness of using coal in the country. Therefore, current analyzes are necessary for the future demand for coal, taking into account ecological conditions, to ensure profitability of fuel extraction and its optimal use. The article presents the situation on the energy market in Poland in the aspect of using coal for electricity production and the forecasted demand for coal.

\section{Legal regulations influencing the domestic energy system}

The European premises of the climate policy included in Roadmap 2050 [2] pose a great challenge for the energy sector. The introduction of considerable reductions in emissions in the energy sector practically excludes hard coal from the energy economy [3]. The IED Directive [3] on industrial emissions, which in 2016 replaced the IPPC [5] and LPC Directives [6], introduced restrictive standards for emissions of sulphur dioxide, nitrogen oxide, and dust. The latest environmental requirements refer not only to large production sources (above $50 \mathrm{MWt}$ ), but also smaller ones (above $20 \mathrm{MWt}$ ), including municipal heating plants.

It is estimated that as many as $30 \%$ of professional power plants and more than half of heating plants will be unable to meet the restrictions of the IED Directive. Of this number, the majority will not be suitable for modernisation due to their age; moreover, the costs of adjustment to the Directive's requirements will be huge [7]. In this context it is essential to consider the question whether existing energy plants should be equipped with modern fume extractor installations or whether the decision should be made to decommission them. In addition, in the nearest future, the manufacturing industry in Poland will have to follow very restrictive environmental norms established in the BAT proposals for large combustion plants (LCPs). These proposals, announced in the middle of 2017, imposed highly ambitious environmental norms, covering within in their range of application emissions of substances listed as harmful in the report: $\mathrm{SO}_{2}, \mathrm{NO}_{\mathrm{x}}$, dust, and, additionally, $\mathrm{Hg}, \mathrm{HCl}, \mathrm{HF}$, and $\mathrm{NH}_{3}$. According to the IED Directive, installation operators will have 4 years from the publication date of the BAT proposals to adjust current installations to the requirements. It follows that before 2021 the entire conventional energy sector, not only in Poland but also in other states of the European Union, will have to undergo thorough modernisation. This means that in the nearest future the domestic energy system will change its energy strategy due to diminishing fuel resources and the increasing impact of environmental conditions. However, the reduction of emissions, especially $\mathrm{CO}_{2}$, should not be accomplished by means of the drastic expulsion of coal from the Polish energy mix. Rather, the changes should be made through investments in modern technologies reducing $\mathrm{CO}_{2}$ emissions and the construction of more efficient energy plants. 


\section{Energy policy of Poland}

Polish energy policy is predominantly based on domestic hard- and brown-coal resources. This is mainly the effect of rich deposits of fossil resources and significant dependence on natural gas imports. Following the EU regulations, the domestic energy mix is undergoing a transformation, resulting in an increase in the contribution of renewable energy sources to the domestic energy structure, as shown in Fig. 1. The diagram compares the structures of the energy mix in 2016 and 2017. It can be noted that a rise occurred in 2017 in RES, natural gas, and petroleum shares.

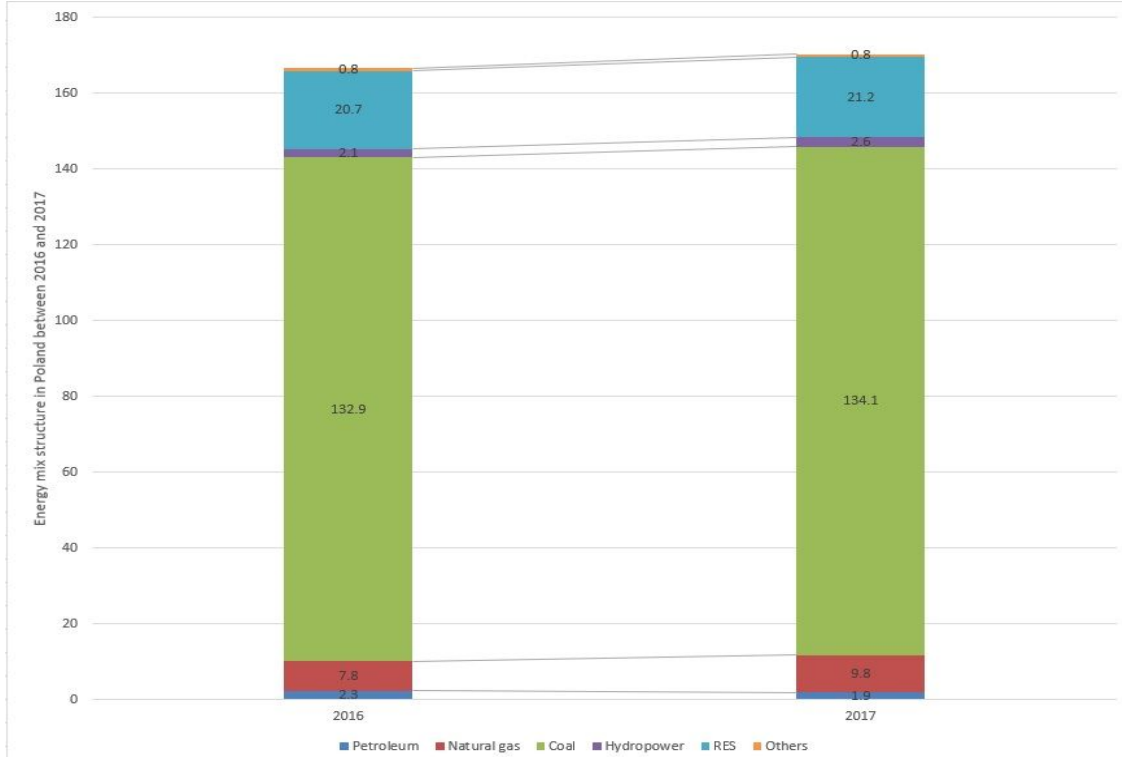

Fig. 1. Energy mix structure in Poland between 2016 and 2017 (author's own study)

Hard coal remains a basic primary energy carrier in Poland. Although its consumption in the professional energy sector is decreasing annually, as shown in Fig. 2, its share is still significant.

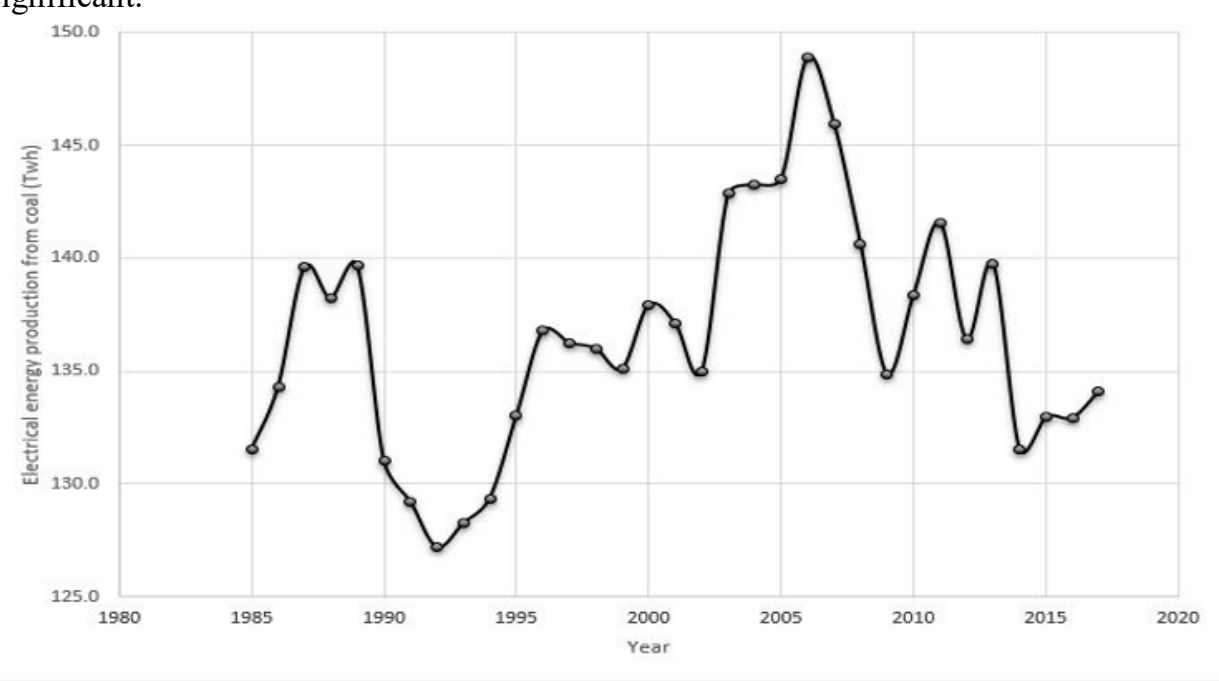

Fig. 2. Electrical energy production from coal (TWh)/years 
The commercial energy sector uses hard coal with varied parameters to produce energy. The parameters of coal in the working state fluctuate: calorific value $19-23 \mathrm{GJ} / \mathrm{Mg}$, ash content $12-30 \%$, sulphur content $0.6-1.2 \%$, chlorine content $0.1-0.3 \%$. It is obvious that hard-coal mines supply the market with energy coal characterised by crucially diversified quality parameters, which is indicative of the large production capacity of the coal sector. Given the current quality requirements for coal, the problem of mechanical coal treatment, which determines the quality of commercial coal, has become especially important. The issue of purifying coal output intended for the energy sector, known as enrichment, has been a topic of discussion for several decades. There is an ongoing debate on the advisability of improving the quality of commercial energy coal with respect to the combustion boilers used by the professional energy sector [8].

\section{Actions and concepts concerning the structure of electrical energy production}

Along with Denmark, Estonia, and Romania, Poland belongs to the group of EU member states which are the least dependent on fossil fuel imports. However, due to a drop in the rate of hard-coal extraction and its share in the structure of electrical energy production, the rate of energy dependence in Poland rose from $0.8 \%$ in 1990 to $29.3 \%$ in 2015. For the EU, this rate rose in the same period from 44.2 to $54.1 \%$. The EU's dependence on fossil fuel imports reached the level of $73 \%$ in 2015 , higher by $20 \%$ than in 1990. Both rates have risen, even though the EU has already spent about $€ 1$ trillion on RES development [9].

In order to maintain the lowest possible prices of electrical energy and to avoid increasing its dependence on imported energy resources, Poland has begun construction of coal power plants. Using domestic national energy resources, which guarantee energy security, is in the political and economic interest of the country. A sudden abandonment of coal or an abrupt reduction in its consumption could seriously endanger this security. However, the energy strategy of Poland assumes a decline in the importance of coal in the structure of electrical energy production, corresponding to the premises of the energy policy.

While basing its energy security on domestic coal resources and abstaining from the construction of CCS installations, Poland is determined to protect the climate by raising the capacity of $\mathrm{CO}_{2}$ absorption through ecosystems, especially forests and systems in urban areas. The country presented this idea in December 2015 at the COP-21 Conference (Conference of Parties), in relation to the fact that Poland is among the most afforested EU member states. Forests cover over 9 million ha, i.e. about one-third of the country's area. Considering that one hectare of forest absorbs 9 million tons of $\mathrm{CO}_{2}$, forests are capable of absorbing almost $30 \%$ of the country's $\mathrm{CO}_{2}$ emissions annually. Moreover, Poland has more than 2 million hectares of infertile soil which does not guarantee cost-efficient agricultural production and therefore can serve as a source of additional $\mathrm{CO}_{2}$ absorption, following afforestation [10].

\section{Hard-coal sales}

As of 1 January 2017, there were 22 operating hard-coal mines in Poland. The organisational structure of the mining sector was as follows:

- Entities extracting hard coal:

-Polska Grupa Węglowa, Inc. - 5 mines;

-Katowicka Grupa Kapitałowa, including Katowicki Holding Węglowy Inc. - 4 mines; 
- Jastrzębska Spółka Węglowa Inc. - 5 mines;

- Tauron Wydobycie Inc. - 3 mines;

- Węglokoks Kraj Ltd. - 2 mines;

- Lubelski Węgiel 'Bogdanka' Inc.;

-ZG Siltech Ltd. (100\% shares held by a private owner);

-ZG Eko-Plus Ltd. (100\% shares held by a private owner);

-PG Silesia Ltd. (100\% shares held by a private owner);

- Restructuring companies which are in charge of liquidating mines following completion of the coal extraction process and which are responsible for managing the mines' assets not connected with production:

- Spółka Restrukturyzacji Kopalń Inc.

The sole owner of the companies mentioned above is the State Treasury, except for Lubelski Węgiel 'Bogdanka' Inc., Polska Grupa Węglowa Ltd., and Siltech Ltd., in which the State Treasury owns over $90 \%$ of shares [11].

Hard-coal mining in Poland delivers mainly raw material for the commercial energy sector and commercial coking and heating plants. It also serves, albeit to a lesser degree, various groups of consumers through authorised dealers. Polish coal is also exported, for instance, to the Czech Republic and Germany.

Hard-coal sales on the domestic market are trending downwards, as shown in Fig. 3.

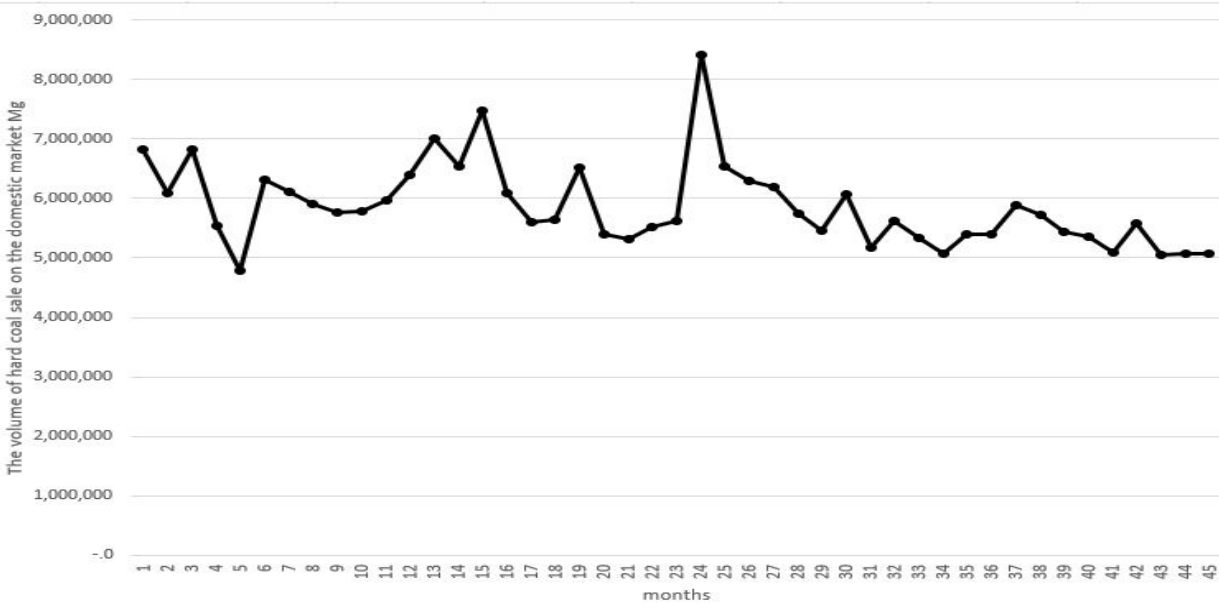

Fig. 3. Hard-coal sales (author's own study)

The diagram shows that the decrease in the level of sales is significant. The data shows sales from 2007 to June 2018. It is clear that 2017 sales decreased by $9 \%$ compared to 2016. The highest level of sales in the analysed period was recorded in 2007, amounting to 89 mil Mg, which signifies a drop of $17 \%$ by 2017 .

A review of the literature, as well as of forecasting methods and practices, extraction programming, and sales, and an analysis of production strategies used and applied in mining prove the necessity of developing methods and techniques of production organisation and management capable of satisfying the changing quality and quantity needs of hard-coal consumers $[12,13,14]$. The study shows a mathematical sales model enabling an explanation of the nature of the seasonality phenomenon in the mining sector and a prediction of the course of production and sales in the nearest future, which will in turn facilitate synchronisation with consumers' needs. An accurate forecast of demand enables not only flexible and dynamic adjustment of levels of production or reserves to changes occurring in the market, but also the adjustment of assortments produced to consumers' 
needs and expectations, which translates into an increase in sales, a release of funds, a decrease in operational costs, and an increase in mines' accounting liquidity.

\section{Methodology: mathematical model of research}

The aim of this paper is to determine the role of hard coal mining in meeting the country's energy needs by providing synthetic results of domestic demand forecasts for hard coal, mainly for the production of electricity and heat. The mathematical modeling methods were applied for forecasting the mutual interactions between coal mining and energy sector. Currently, they an commonly used for solving problems related to the complexity of the fuel and energy systems $[15,16,17,18]$. The choice of the model has been discussed in detail in the works [18, 19]. Among forecasting models, an important role is played by autoregressive and moving-average models, which determine the relationship between the values of a forecasted variable in a period $t$ and the values of the variable from previous periods $\mathrm{t}-1, \mathrm{t}-2, \ldots . ., \mathrm{t}-\mathrm{p}$ with an accuracy to a random component [20]. A model of this type is used quite often in practical situations, since, when forecasting economic phenomena, one can find many situations indicating delays in the courses of certain phenomena. For example, demand for hard coal is characterised by delays connected with heating periods.

\section{Results of research}

The theoretical model was built by isolating individual components, which made it possiblel to understand mechanisms generating a studied series. As a result, the model may contribute to improving the accuracy of forecasts.

The decomposition of a series of hard-coal sales was conducted by means of:

- isolating the trend;

-conducting a modified harmonic analysis using the discrete Fourier transform in order to determine the relevant seasonality.

The basis for identifying the model in the auto-regressive part is the empirical functions of autocorrelation and partial autocorrelation. In Figs. 4 and 5 the values of these functions for delays $\mathrm{p}=1,2, \ldots \ldots 15$ are presented.

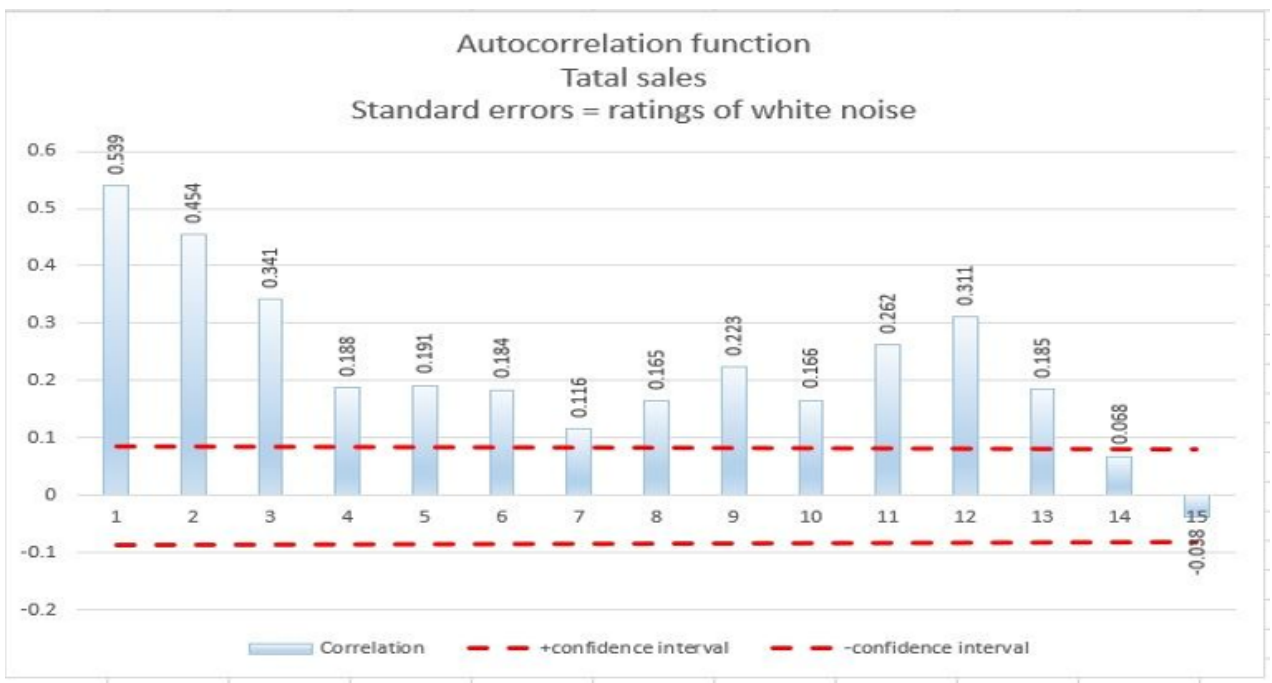

Fig. 4. Empirical autocorrelation function built for a series of sales (author's own study) 


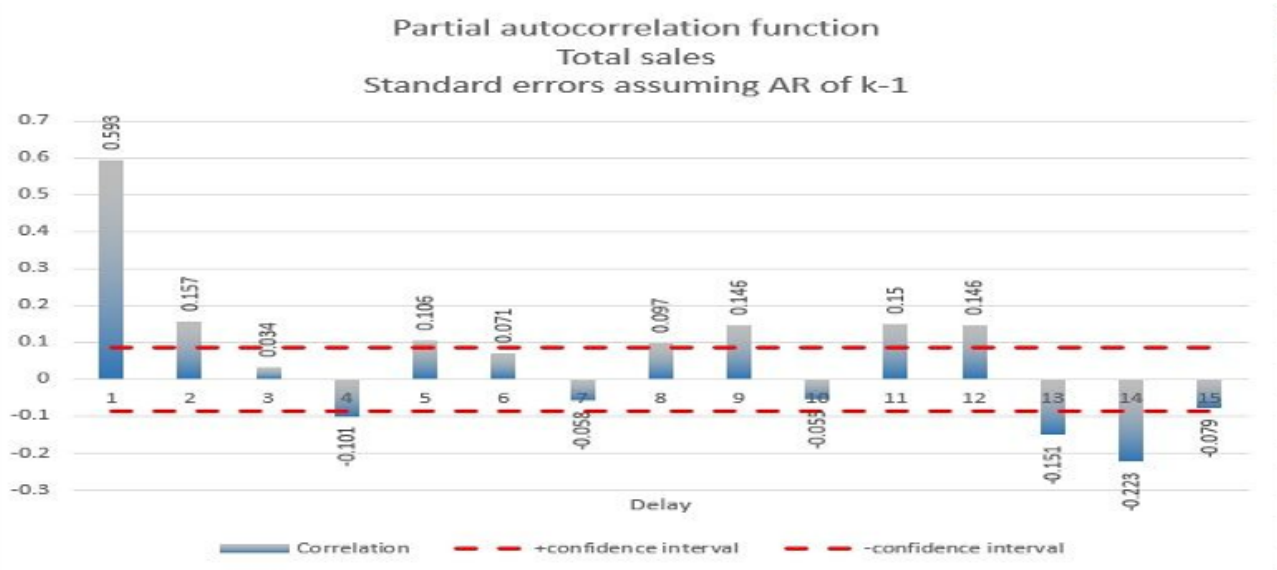

Fig. 5. Empirical partial autocorrelation function built for a series of sales (author's own study)

Estimation of the parameters in the auto-regressive part of model was conducted using the STATISTICA package by means of the maximum likelihood method of McLeod and Sales. The preliminary estimations of parameters obtained from Yule Walker's equations were assumed as the initial values of the iterative procedure. In the case of the autoregressive part of the model, the empirical value of the partial autocorrelation for $d=1$ was assumed, whereas the mean value of the considered time series was assumed as the preliminary estimation of a part of moving average. The optimum order of the model was determined by means of AIC information and BIC criteria. The model for which the value of coefficients was the lowest was chosen:

$$
\begin{aligned}
& \mathrm{AIC}=3542.12 \\
& \mathrm{BIC}=3553.31
\end{aligned}
$$

The model describing the phenomenon of demand for hard coal was defined as the model with the ARIMA form $(0,1,1)(1,1,1)$.

The theoretical values obtained from the developed model are presented in Fig. 6.
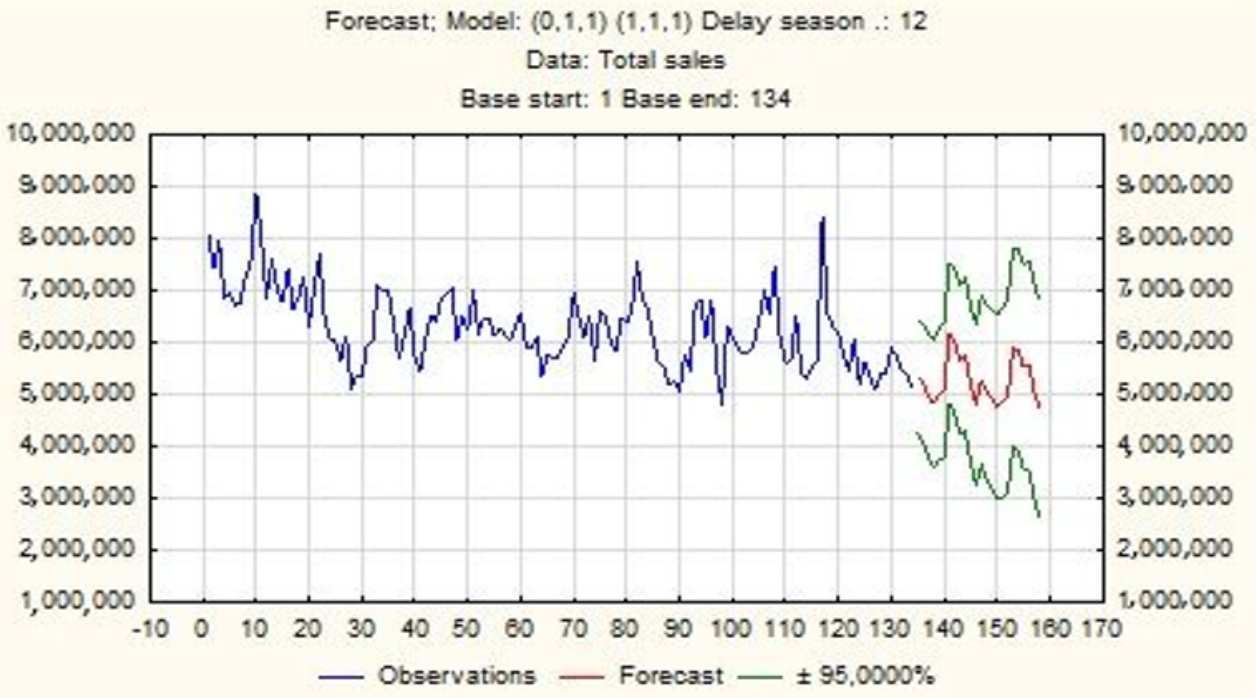

Fig. 6. Theoretical model of the volume of demand for hard coal ARIMA $(0,1,1)(1,1,1)$ (author's own study) 
To determine the accuracy of the model's adjustment, autocorrelation of rests $\Upsilon_{g}(d)$ was determined for intervals $d=1, \ldots . .15$. The diagram of the autocorrelation of rests (Fig. 7) of the estimated model shows that no coefficient exceeds the limit $\pm 2 s_{r_{g}(\boldsymbol{d})}$, which means that none differs substantively from zero.

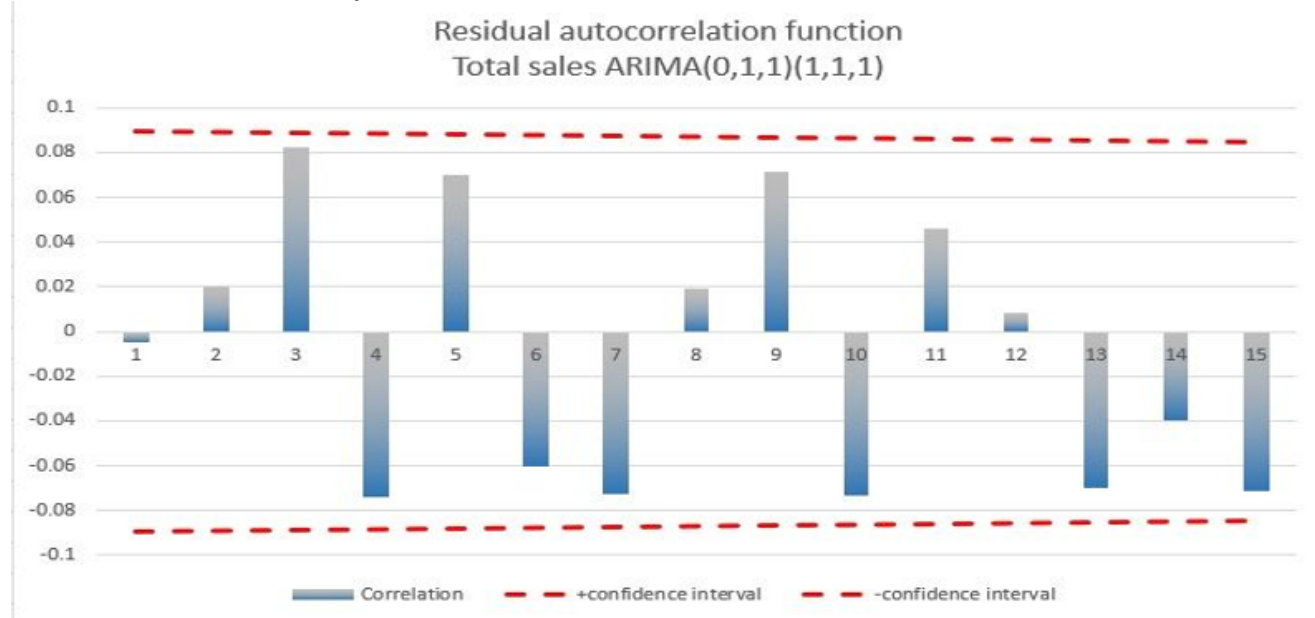

Fig. 7. Autocorrelation of the rests of the ARIMA model $(0,1,1)(1,1,1)$ (author's own study)

The lack of autocorrelation is also proved by the histogram of the distribution of rests (Fig. 8), where the normal curve is very well adjusted to the distribution.

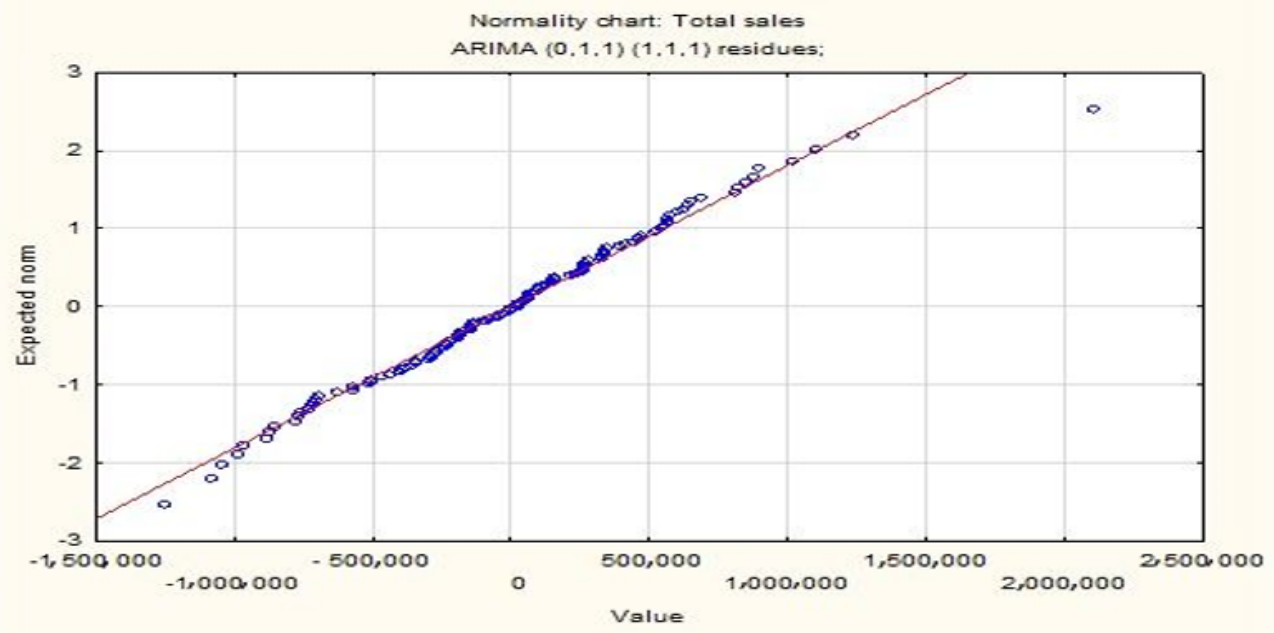

Fig. 8. Normality of rests (author's own study)

This means that the model can be used to forecast demand in the domestic market. On the basis of the constructed theoretical model, a decrease in coal sales can be observed.. The drop is $2 \%$ compared to the base year (2017). The drop will continue over the coming years, which means a decrease in sales in the domestic market, to both the professional and industrial energy sectors as well as to other consumers.

The theoretical results obtained from the ARIMA $(0,1,1)(1,1,1)$ model can be referred to real data. The results of the comparison are plotted in Fig. 9 (Total hard coal sales in 2019 year). The error of the developed model is MAPE $=2 \%$, which allows for the creation of accurate forecasts. In addition, the generated forecasts are interval, which can be 
interpreted with $95 \%$ interval of confidence as optimistic, pessimistic and the most probable variant.

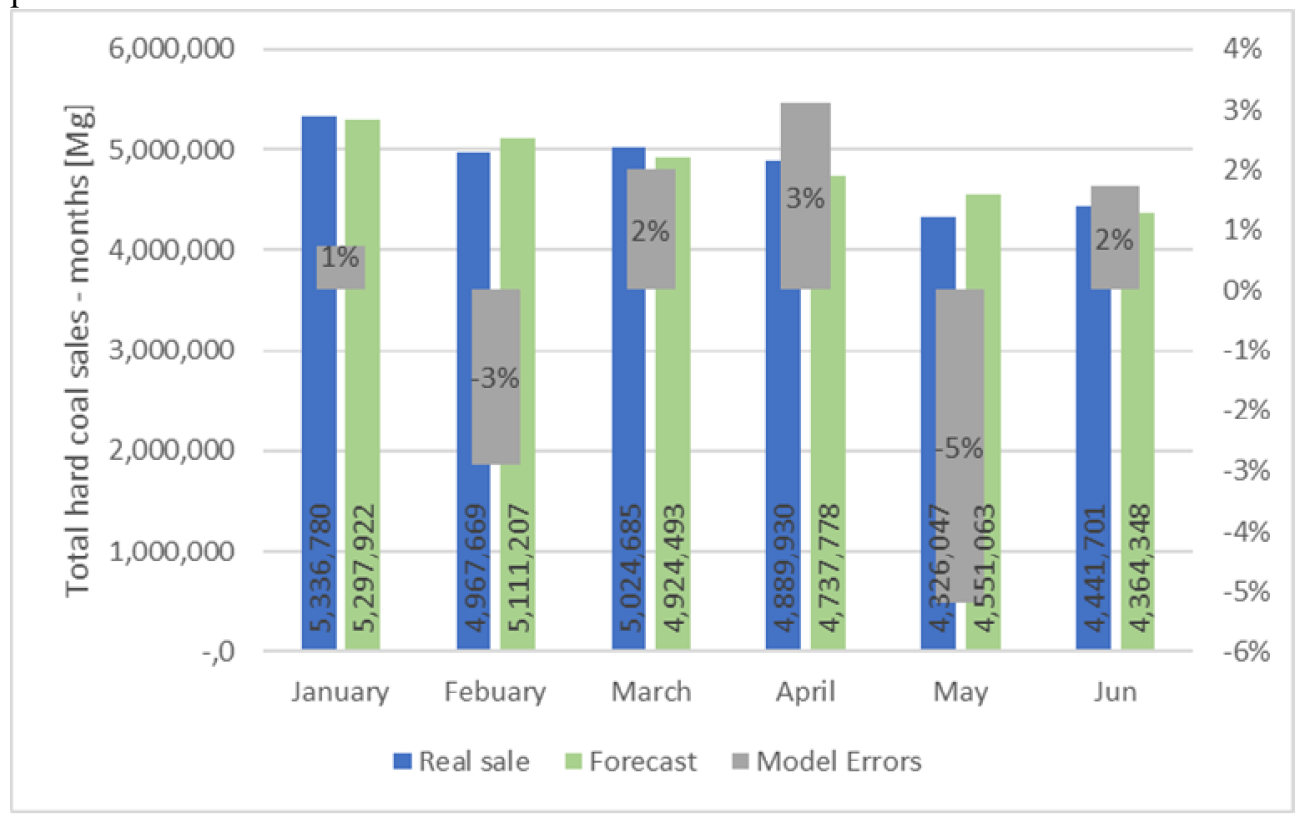

Fig. 9. Comparison of the theoretical model data with real data (author's own study based [21])

The error of the developed model is MAPE $=2 \%$, which allows for the creation of accurate forecasts. In addition, the generated forecasts are interval, which can be interpreted with $95 \%$ interval of confidence as optimistic, pessimistic and the most probable variant.

\section{Conclusions}

When developing the theoretical model, emphasis was placed on taking advantage of all technically available technologies of producing electrical energy from coal, assuming that each of these solutions can be adjusted in terms of reduction of emissions. This also applies to adjustment of the preparation of coal with various quality parameters and varied grain characteristics to the requirements of a given technology of electrical energy production. The analysis shows that autoregressive models and models of moving average can be used for econometric forecasting, an example of which is the constructed model ARIMA $(0,1,1)$ $(1,1,1)$, which forecasts demand for hard coal. In the case of an analysis of econometric phenomena, many factors influence the analysed processes. In the case of the demand for energy coal, these factors are as follows: availability of resources in other countries, the price and quality parameters of types of coal, and technological developments in the mining industry. Introducing all of this information into models may cause a reduction in their accuracy due to errors in forecasting each of the mentioned parameters.

Autoregressive models should be applied mainly in short-term forecasting, as, over the long term, forecasted values approach the conditional expected value, which is frequently the average value of the analysed time sequence.

Acknowledgements The present paper was elaborated within the framework of the statutory research [06/030/BK_17/0030]. 


\section{References}

1. The Ministry of Energy: Energy Policy of Poland until 2040 (2019)

2. A roadmap for moving to a competitive low carbon economy in 2050. SEC (2011) 288 final, Brussels (2011)

3. R. Szczerbowski, B. Ceran, Energy policy of Poland in the context of the challenges of the 21st century, Energy Policy Journal, 28/1, 5-20 (2018)

4. Directive 2010/75/Eu of the European Parliament and of the council of 24 November 2010 on industrial emissions (Integrated Pollution Prevention and Control), (2010)

5. Directive 2001/80/EC of the European Parliament and of the Council of 23 October 2001 on the limitation of emissions of certain pollutants into the air from large combustion plants, (2001)

6. Directive 2008/1/EC of the European Parliament and of the council of 15 January 2008 Concerning Integrated Pollution Prevention and Control, (2008)

7. P. Stępiński, The European Commission for the integration of the Baltic energy system by Poland. [Online] http://biznesalert.pl/komisja-europejska-za-integracja-systemuelektroenergetycznego-baltow-z-pomoca-polski/ [accessed on 29.07.2017]

8. I. Baic, W. Blaschke, W. Sobko, A New Method for Removing Organic Contaminants of Gangue from the Coal Output Middle Pomeranian Scientific Society of the Environment Protection, The Environment Protection, 17, (2015)

9. Eurostat, Energy consumption in the EU below its 1990 level but EU dependency on fossil fuel imports on the rise Eurostat, (2016)

10. A. Pawłowski, M. Pawłowska, L. Pawłowski, Mitigation of green gases emissions by management of terrestrial ecosystems. Ecological Chemistry and Engineering 24(2), 218 (2017)

11. H. Paszcza, Hard coal mining in Poland in 2016, Wiadomości Górnicze, 6, (2017)

12. A. Manowska, Forecast to determine a development strategy for the mining sector. 18th International Multidisciplinary Scientific GeoConference SGEM, 967-97, (2018)

13. A. Manowska, Main risks for Polish energy security 18th International Multidisciplinary Scientific GeoConference. 593-600 (2018)

14. L. Gawlik, M. Kaliski, J. Kamiński, A.P. Sikora, A. Szurlej, Hard coal in the fuel-mix of Poland: the long-term perspective, Arch. Mining Sci., 61/2, 335-350 (2016)

15. A. Manowska, K. Tobór-Osadnik, M. Wyganowska, Economic and social aspects of restructuring Polish coal mining: Focusing on Poland and the EU, Resour. Policy, 52, 192-200 (2017)

16. E. Morawski, Restructuring the hard coal mining industry in Poland, Resour. Policy, 20/3, 193-197 (1994)

17. J. Dubiński, M. Turek, Chances and threats of hard coal mining development in Poland - the results of experts research. Arch. Mining Sci., 59/2, 395-411 (2014)

18. A. Manowska, Practical application of selected panel data techniques in analyzing sales capabilities of coal assortments, Enterprise and competitive environment. $21 \mathrm{st}$ Annual International Conference, Brno, Czech Republic, 415-423 (2018)

19. A. Rybak, A. Manowska, The forecast of coal sales taking the factors influencing the demand for hard coal into account, Gosp. Sur. Miner., 35/1, 129-140 (2019)

20. E. Bielińska, Identyfikacja procesów, Wydawnictwo Politechniki Śląskiej, Poland, 63 (1997)

21. Industrial Development Agency polskirynekwegla.pl/raport-dynamiczny/sprzedazwegla-kamiennego-ogolem-miesiace [accessed on 29.08.2019] 